\title{
Sodoran as a Means of Intromission Education for Tenggerese Younger Generation
}

\author{
Sony Sukmawan ${ }^{1}$, M. Andhy Nurmansyah ${ }^{2}$, Rahmi Febriani ${ }^{3 *}$ \\ Fakultas Ilmu Budaya, Universitas Brawijaya,Jalan Veteran, Malang, Indonesia ${ }^{1}$ \\ Fakultas Ilmu Budaya, Universitas Brawijaya,Jalan Veteran, Malang, Indonesia ${ }^{2}$ \\ Fakultas Ilmu Budaya, Universitas Airlangga,Jalan Dharmawangsa Dalam, Surabaya \\ Indonesia $^{3}$ \\ \{rahmifebriani2@gmail.com ${ }^{3\}}$
}

\begin{abstract}
The various Tengger traditional arts, especially Sodoran dance, contain positive values about life. It is said so due to its performance that symbolically tells about the life cycle, portraying from where the life comes from-how to live the life-and where life is going to end. This dance is potential to be used as a means of intromission education. Therefore, this study aims to comprehensively describe Sodoran to sharpen understanding and strengthen knowledge for the Tenggerese young generation toward Karo ceremony and Sodoran dance. For this reason, this research is designed as qualitative research with the ethnography method to takes precisely Tenggerese view of life as the object of the study. The data collected for this research are in the form of folklore performances and collected by interview, observation, and group discussion. The data analysis process is done by codifying data (open coding), breaking down, checking, examining, comparing, conceptualizing, categorizing, axial coding, and display code. The result is a complete description of (i) various ritual facilities and properties loaded with philosophical values; (ii) meaning of dance movements as pictures of life journey or sangkan paran; and (iii) its relevance as a means of intromission education for Tenggerese young generation through what is known as titiluri.
\end{abstract}

Keywords: Sodoran; intromission education; titiluri; young generation

\section{Introduction}

Sodoran Tengger is the main annual tradition in celebrating Karo day. This tradition is wrapped in art performance and consistently held at the opening of Karo ceremony. Besides Sodoran, Karo day (holiday) is also enlivened by the presence of various regional art performances both typical of Tengger and coming from outside Tengger. Bantengan, kuda lumping, drum band, and barongsai (Chinese lion dance) are some art performances originating from outside Tengger which enliven the event. Meanwhile, ujung dance, tayub, and of course sodoran are typical arts of Tengger which is always performed in some stages of a celebration of the feast. 
Sodoran dance is distinct and unique compared to the types of art previously mentioned. If most of the arts are performed and responded by the audiences with much fanfare and happiness, Sodoran is delivered and witnessed solemnly and emotionally. Sacred nuance is presented from the beginning of the performance, starting from puja japa pandita, and then the introductory ritual at the temple for the dancers, up to sacred ritual properties that accompany it. Some of the properties include rhythmic sounds of gamelan (Javanesetraditional music instrument), scattered dupa (smoking incense) and offering for ancestors, as well as bamboo Sodor which is sacred and loaded with symbolic meaning.

The entire stages of Karo ceremony and the entire process of sodoran dance contain symbolic meaning. Therefore, the properties included in the ceremony and ritual also carry on symbolic meaning in it. The symbolic meaning of Karo and Sodoran is related to the virtues of life for humans and the universe. These virtues compile so many aspects of life from moral, ecological, socio-cultural, political, economic, religious, to youth educational values.

The youth educational process through culture has not been optimized. This pathway is more promising, however, applied to communities that still hold firmly traditions and customs such as Tengger community. The cultural approach to educate Tenggerese younger generation is very prospective considering three things. First are that tradition and art bind people. Second, there are quite a lot of cases of early marriage due to cases of pregnancy before marriage. Third, the Tengger community has many traditions that contain values of youth education (such as Sodoran).

In the preliminary study, however, it is found out that not many young people in Tengger understand comprehensively the essence of moral teachings within their traditions. Most of them only do titiluri. Titiluri is a principle of cultural obedience to everything that has been practiced by the ancestors. Unfortunately, 'unconditional' obedience as a strong motive for comprehending and internalizing tradition is not fully understood. Therefore, the diffusion of the essence of moral teachings within traditions is limited in its scope. Titiluri should be understood as a holistic package combining action and understanding about the essence of tradition. By performing titiluri as a whole, the resilience of tradition can be maintained intensively and extensively.

Research on Karo and Sodoran dance has been conducted by several researchers, among them Nurmansyah, et al. (2019) and Ratih and Juwariyah (2020). Nurmansyah, et al. (2019) conducted a study titled Tayub Dance within the Realm of Karo Rituals of Ngadas Village. The study aims to trace the "newly-structured" Karo ritual performance and interpret it for millennials at Tengger. These results found that there was hybridity of a mix between Karo and Tayub as a medium to negotiate with their generation to stay involved in the ritual. This study also discussed how structural changes in Karo resulted from the replacement of Sodoran dance with Tayub. Nurmansyah, et al. (2019:291) mentions that Karo ritual in Ngadas has been modified so that its values are no longer the same.

Meanwhile, Ratih and Juwariyah's research (2020) titled Social Construction of Karo Ceremony of Tenggerese in Tosari Village, Tosari, Pasuruan has focused the study on Karo. Karo was researched sociologically to see how social construction formed in it. This result shows that there were three functions of traditional ceremonies, those are (i) spiritual functions indicating that Karo was a means of conveying gratitude to the ancestors; (ii) social function is indicated by the social activity in Karo; and (iii) the tourism function explains that Karo provides opportunities to attract tourists coming to Tengger. Meanwhile, the stage of social construction is drawn from three things, (i) the stage of preparing construction materials reflected in the ceremonial preparation activities by the Dukun Adat, the stage of construction 
distribution reflected in the division of each person's duties, and the stage of construction formation reflected from the implementation of Karo ceremony in its entirety.

The studies above have the same scope of the study which is Karo ritual as a whole. However, it did not discuss Sodoran as part of Karo comprehensively. Nurmansyah's research, et al. (2019) focused on Tayub dance and Ratih and Juwariyah (2020) focused on Karo ceremony, they did not discuss how Karo and Sodoran were related and how it had implications for Tengger's youth education. Thus, Sodoran dance is still being a part of other study objects. In other words, Sodoran dance is not the main focus as an object of study.

Likewise, the Karo commemorative habit is characterized by Sodoran dance. The subtlety

of ancestors' feeling which is bound by udanegara and a matter of politeness in delivering the notion of Sangkan Paran which is the origin and the purpose of human's life journey, have to be delivered symbolically. According to the ancestors, it is very impolite or improper to talk about sangkan overtly. It is one of the taboos. Eventually, the essence of moral teachings which is wrapped up with beautiful symbolical expressions is getting blurred. If the bearers of tradition cannot understand it, the interpretation of others (outsiders) will be based merely on logic. Their (outsiders) interpretation will certainly be away from the essence of faith that fosters the habit. Different understandings of "kemantas" become inevitable. To avoid further biases and blurring understanding, stories from all parties are gathered, especially those from the elders of Tengger... (Narration of Sodoran Performance)

Based on the previous research that has been mentioned, this study seeks to reveal a more comprehensive understanding of Sodoran from Tenggerese elders to extend its moral teachings and its meaning. By this, it is hoped that this study will bring impact on sharpening and strengthening the understanding of younger generation in Tengger about one of their own traditions. For that reason, the focus of the study is divided into two (i) the description of stages of sodoran dance (ii) movements, instruments/properties, and offerings as symbolic messages.

This study is important for actualizing of local tradition within the realm of millenial contemporary life. This study is also an answer of how traditional values are and how they should adjust the social change. Tradition should be able to welcome global change while at the same time maintaining itself not losing its essential moral teachings. Furthermore, Sodoran performance will become the main foothold of the study. Therefore, literary studies and literary performances become theoretical and methodological bases. By aiming to this focus, it is hoped that the result will be able to create the convergence of studies targeting various outside dimensions. The multidisciplinary study including socio-cultural, economic, ecological, and educational studies that are based on the oral-literary study is expected to solve the research problem accurately and comprehensively.

\section{Method}

This research is designed as qualitative research with the ethnography method. This kind of research seeks to study a cultural event and takes precisely the Tenggerese view of life as the object of the study. The focus is related to how Tenggerese lives, thinks and behaves. Locuses of this research are some villages in Tosari district in Pasuruan residence namely Mororejo village, Ngadiwono village, Wanamerta village, and Telagasari village.

The data collected for this research are in the form of folklore performances that are manifested in oral expressions or utterances, in symbolic actions or behaviors which contain 
ideas, messages, and values related to intromission education for the younger generation in Tengger. The data are obtained from Tengger community including cultural bearers such as dukun pandhita (the shaman), sesepuh (the elders), dukun alit (midwives), local artists, and some tradition performers. Furthermore, the data are collected by interview, observation and group discussion then analyzed. The data analysis process is done by codifying data (open coding), breaking down, checking, examining, comparing, conceptualizing, categorizing, axial coding, and display code (Endraswara, 2018:95-96).

\section{Discussion}

\subsection{Symbolic Meaning in Dance Properties}

The prominent property in the Sodoran dance is kecrek or Sodoran bamboo. Its onomatopoeic name of the instrument is derived from the sound 'crek' produced by the property when it is used by the dancer in dancing. It is also said sodor (submission) because it is used for nyodor (to submit oneself). In the process of making the property, anyone can take the material from the forest and there is no specific condition to fulfill on who should make it. The maker can be Pak Sepuh or Pak Legen.

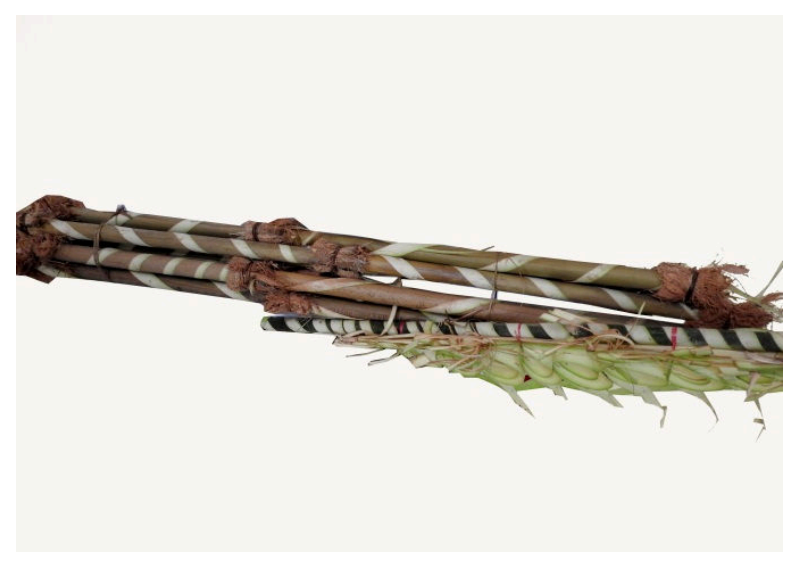

Figure 1. Kecrek or bamboo Sodor

Material needed in making kecrek are wuluh bamboo (known alsa as java bamboo or black bamboo or Gigantochloa atroviolacea), penjalin (rattan as a rope to tie) or branding (shavings of bamboo), sepet (coconut fiber), leaf, and wiji (a kind of nutmeg). The method of making it is simple, namely (i) cutting the bamboo wuluh $150 \mathrm{~cm}$ long, (ii) wrapping the leaf along the bamboo, (iii) inserting the seeds into the top and bottom of the bamboo-segment, (iv) closing it with the sepet the top and bottom holes of the bamboo. The last is wrapping the sepet in the middle of bamboo, by being tied using rattan or branding.

Wuluh bamboo is a symbol of wolu, loro, sepuluh (number 8, 2 and 10). Wong Tengger (Tenggerese) has a Dasawara that must be acted on. The Dasawara consists of sabar (indulgent), nrima (amenable), bening (pure in heart and mind), eling (religious), titi (thourough), ngerti (to understand), geming (firm), ati-ati (wary), ila-ila (prohibition), and nglakoni (to act). The Sepet is a symbol of feeling happy, hard, and sad. In other information, 
it can also explain the state of sebat (discomfort, and unpleasantness). Meanwhile, Wuluh bamboo represents a pleasant side. It symbolizes a phallus (male genital). In brief, wuluh bamboo and sepet is a symbol of life's journey that has ups and downs. Meanwhile, janur describes sanctity and the sacred of love. As described in the following quote.

Janur symbolizes things that are actually very sacred therefore they are wrapped. The Janur symbolizes a sacred gift or nurcahya. Those are holy thoughts. So, the Janur is a picture of love that is sincere or holy. People who do (intimate relationships) must be based on love, not only based on desire, but also must be with love. "(Shaman Keto, interviewed on April 2020)

\subsection{The Offerings of Ritual of Mblarai Sodoran}

The offerings of the ritual of mblarai sodoran include some flowers usually called as kembang gubahan (namely: senikir, tanlayu, jagut, putihan, and tlotok), traditional snacks, gedhang ayu (banana), a glass of water, and a glass of coffee. The kembang gubahan is a type of offerings that will be placed in places that contain water. The offerings which contain various flowers are given to gods who are in charge of guarding the springs, especially the guardians of the four springs (banyu macapat) namely utara (North), timur (East), selatan (South), and barat (West). Aside from being placed in a spring in the village, the kembang gubahan is also placed in the bathroom or a water reservoir in the house. Plants used for the kembang gubahan are usually found in areas around fields (as wild plants) or deliberately planted by some villagers. Tlotok leaf means telu thok 'only three' (the main ones), which is birth, life, death. Tlotok also means that humans must be right in three ways: thinking, talking, and doing. Senikir leaf has the meaning of thinking (weighing) about things that are good and bad. Tanlayu means eternity.

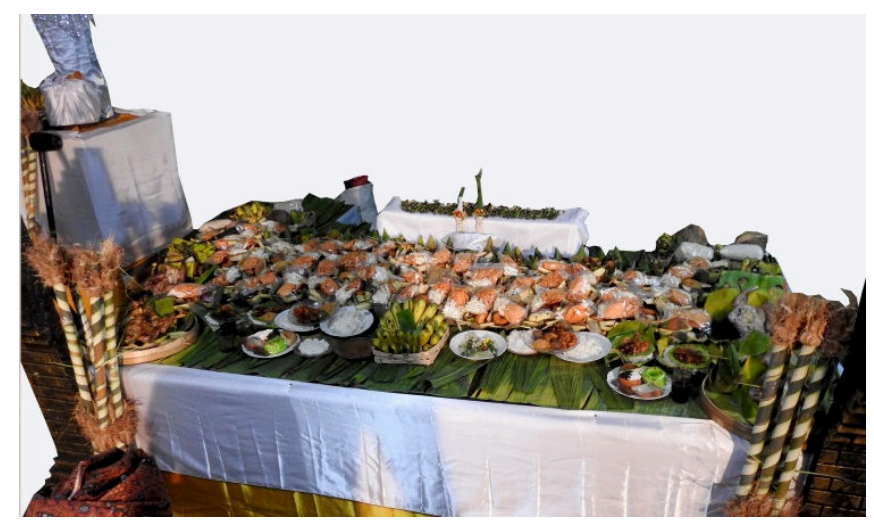

Figure 2 Mblarai Sodoran offerings

In Ngadiwono, the performance of sodoran as a ritual of nyepasari Karo (five days after the oppening of Karo ceremony) must offer 25 pieces of takir janur, 25 pieces of takir Godong, 25 pieces of tumpeng, 25 pieces of side dishes, sega galang, sega roahan, gedhang ayu, pras pertula, and pras among sanding. Another means is bamboo Wuluh as a property used for performances and degan (unripe coconut fruit) which is inserted into a tempayang and a gayung (dipper) as a symbol for floating holy water.

In any ritual process, Gedang ayu is a mandatory because it symbolizes the seats for the invited spirit of ancestors. Gedang ayu is also for other spirits and baureksa (metaphysical 
beings). That is why the place of Gedang ayu is always on top. Gedang ayu is usually wrapped in ider-ider cloth. The composition of the complete offerings of gedang ayu consists of a comb, a cosmetic powder, a glass, cigarettes, and cok bakal in one takir.

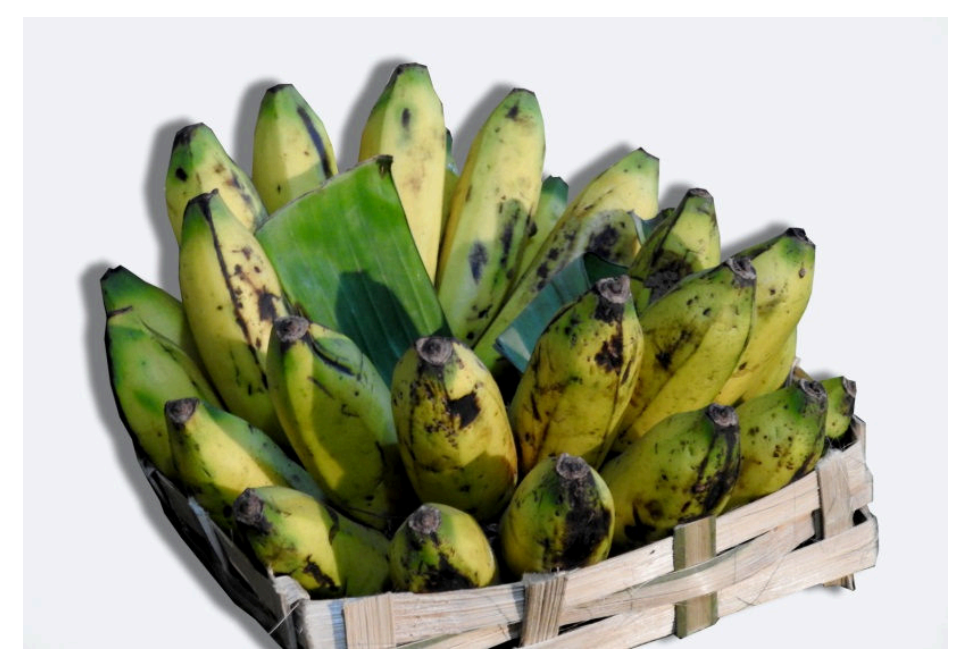

Figure 3. Gedang Ayu

In addition to offerings, some tools must be prepared, including dipper / Jodan to purify the universe; degan as a symbol of purifying water covered with beringi leaves as a symbol of protection; and Jimat Klontong. Jimat Klontong or Ontokusumo shirt is a seamless bushing believed to be able to attach to human skin. In the legend of Tengger, Eyang Tunggak and Eyang Tompo got this heritage after doing meditation. This sacred heritage will be opened after the mblarai ritual and after the Sodoran dance is performed.

\subsection{Dancers' Attributes}

The dancers, both men and women in the Sodoran dance performance (in the opening and closing session of Karo ceremony) wear Tenggerese udheng (a piece of cloth used as head cover whose style of folding is different from other udheng from different regions), white shirt with a Tenggerese logo on top of its pocket, yellow scarf, belt, keris (Javanese traditional weapon/blade) tucked into their belts on their backs, jarik (traditional Javanese cloth), and pants in certain length size that do not cover their ankles.

Furthermore, the clothes used in the sodoran dance "yellow Slempang linggar jati..." and so on this is not merely clothing. This clothing is used in the worship ritual. This outfit symbolizes the real Sulinggih. It is explained through the spell spoken such as "arco patung panggonaniro." This part of spell is spoken while performing worship ritual and is known by Javanese as Lingga Yoni, a place of worship of ancient Hinduism. Lingga Yoni is a symbol of Purusa Pradana which is closely connected to Karo, Jenang, and Sodoran. (Sodoran performance narration) 


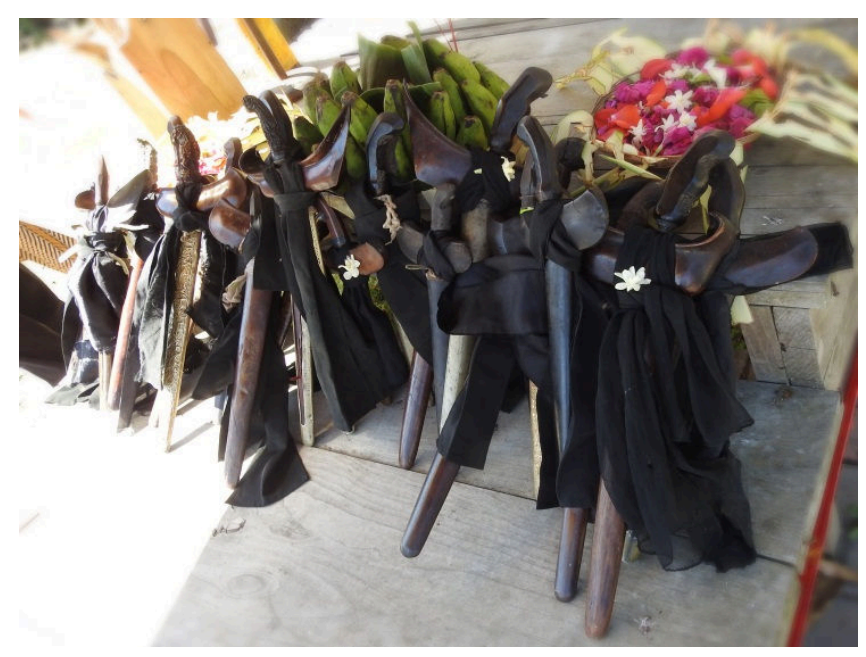

Figure 4. Keris of Sodor Dancers

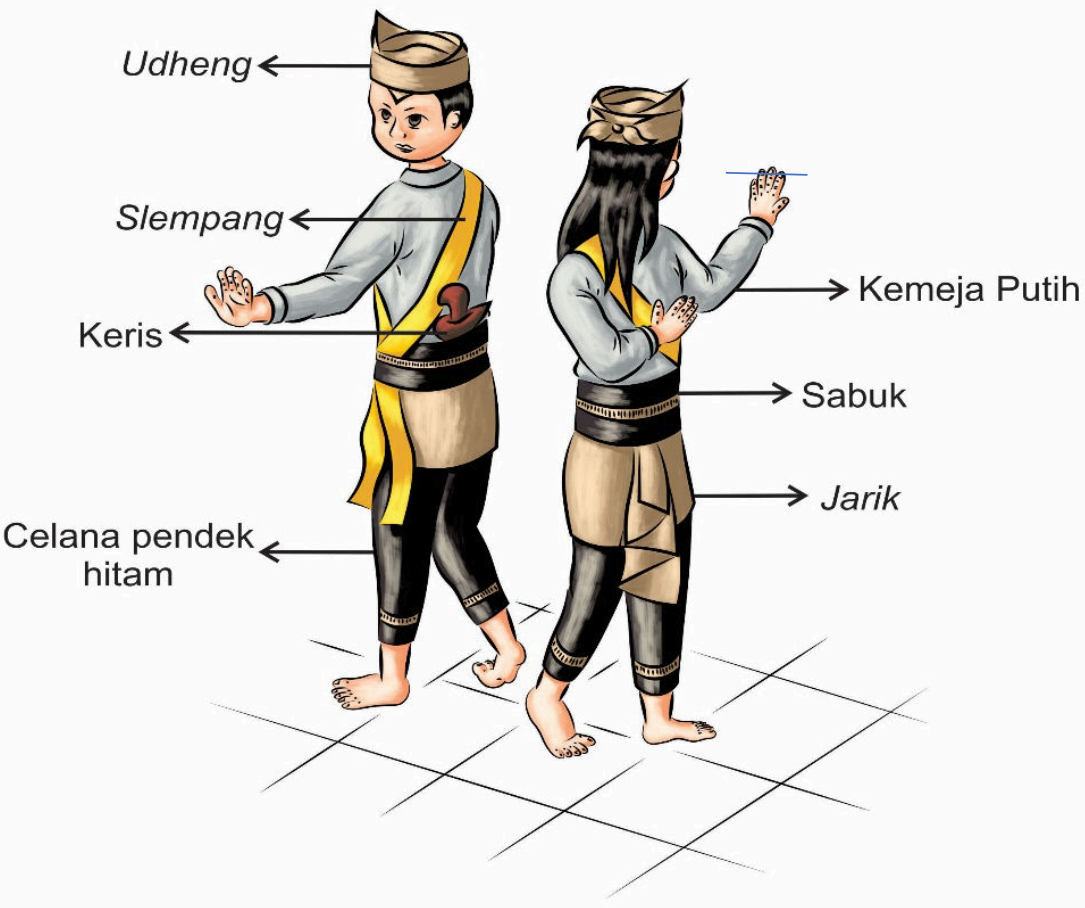

Figure 5. Dancer's attributes in animation 
Clothing for dancers should not be in red, because red color is close to the color of light and sky, meaning it is close to other realms. Suggested variations of color of their dress code are yellow-yellow or white-yellow. The most preferred one, however, is the white-black combination. White is for the shirt and black for the pants. The white color here means sky and black means earth. Yellow slempang is a 'true sampet'. In Tengger's history, yellow slempang was used by shaman in worship. Slempang is a symbol of the sanctity of the soul. When presenting rituals or meditating, a shaman will be bound and covered his soul in purity.

The Sodor dancer uses a slempang that is not crossed as the shaman uses. Yellow slempang or sampet used by the shaman is a symbol of closing babahan hawa nawa sanga, or known as 'refraining' or 'forbearing'. Yellow is a symbol of beauty. The slempang worn by sodor dancers is different in its direction between male and female dancer. Slempang of male dancer crosses from right to left, and the female one is from left to right. 'Right cross' slempang for male dancer means that men should not be fooled or opposed in the familial life. 'Left cross' indicates the dancer is still pure. Moreover, udheng can vary in its model, but the folding pattern must create 'mocopat form' and ended with triangular folds. Udheng which is not following 'mocopat form' may not be used, such as Balinese udheng which is forbidden to use. It is because udheng in Tenggerese tradition symbolizes 'mind binder' (the guardian of thought).

\subsection{Stages of Sodoran Dance: Journey's Description}

In the early morning, around 03.00-05.30 am, at the opening of the Karo Ceremony, Mblaraki ritual is held. In the Mblaraki ritual, there are some series of events, first is delivering Cangkriman Kertijoyo and performing Sodoran Dance. Cangkriman Kertijoyo is an orally-delivered kind of puzzles that contains both questions and answers. Cangkriman Kertijoyo is read by a shaman and his assistance. The shaman is in charge of reading questions and his assistance reading the answers. Before delivering Cangkriman Kertijoyo, someone (called as pelandang) will guide the Sodoran dancer to prepare on stage. The number of Sodoran dancers must be event ranging from four people, eight people, or twelve people. At noon during the peak of the Karo opening ritual, the Sodoran Dance is performed by female, male or mixed dancers.

(Data 01) A long time ago, when performing Sodoran dance, the older generation did not create groups as the younger generations do now. Ahead of the Sodoran ritual, each of the elders was looking for a partner individually to dance. The younger generations of dancers these days have developed their mindset. They form a group of dancers who would represent each village in Tosari region not in a short period of time but they have made and prepared it well in advance. Eventually, nowadays, the elders get their time to perform sodoran dance only in mblarai ritual. " (Shaman Keto, interviewed on April 2020)

The elders begin the opening of Karo ceremony with the Sodoran dance for several reasons. In addition to the cultural regeneration factors as described in (Data 01), the reason is also due to the time of performance. The dance performance in the early morning of the 15 th of sasi Karo (month of Karo) is considered more appropriate performed by male and adult dancers. Meanwhile, the youngers, especially the young women will have got their time to perform at noon on the same day. 


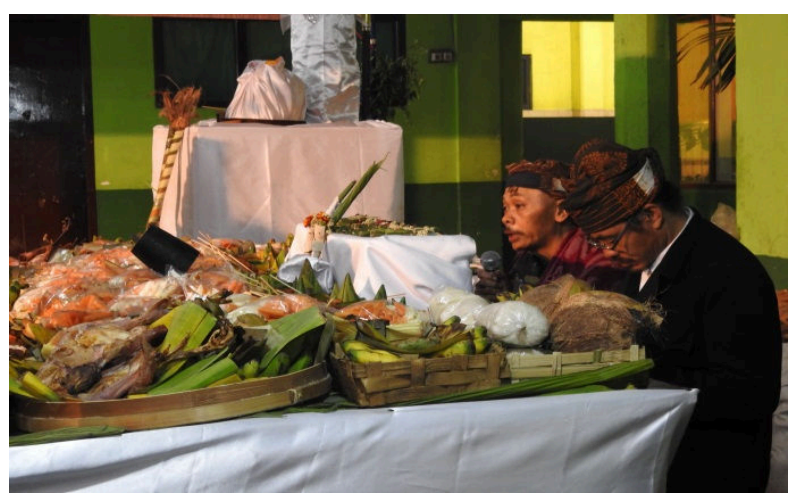

Figure 6. Mblarai ritual procession

Younger sodoran dancers and elders have thought about the importance of making sodoran dance group. They gather male and female dancers not in immediate time to prepare dancers physically, mentally, spiritually, and technically since there are several stages that they must undergo before they are legitimate and eligible to perform this sacred Sodoran dance. Technically, the movements in the Sodoran dance are fairly simple, but dense in meaning. Like other traditional folk dance, Sodoran dance is formed and determined by the music. The patterns of gending and kendangan are already present, so the dancers move following the sound of gending and kendangan. (Minarto, 2008: 196). Though the movements of the dance are simple and uncomplicated, the values of human existence are dense and wrapped up symbolically and euphemistically. (Sukmawan, 2017: 366). At first, the dancers face each other in a sitting position and worshiping. Slowly then they stand up and begin to dance. While continuing to dance, each will come closer to the other.

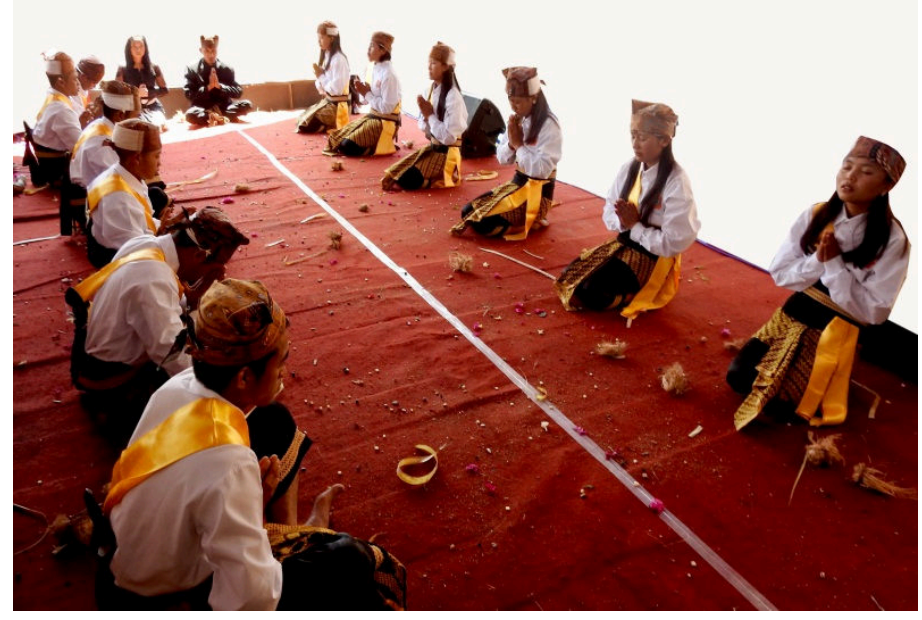

Figure 7. Worshiping posititon

Dance movement in the first session begins with right footwork which is slightly bent. The tip of the right foot is pressed against the left foot until the space between the right foot and the left foot forms a triangle. At the same time with the movement of the right foot, the 
dancers swing their arms to the left side with the position of the left-hand straight (parallel to the shoulder) and the right hand is placed on the chest. Both palms are open facing to the left as well as their faces. If the left-facing movement has been done completely, the dancer will automatically change the position to the 'left foot movement' as the same as the right foot described previously but in contrary direction. In each movement, the dancers lower his body two times by bending the knees. The sound of dungjesss coming from the instrument being played is the signal that every single step of movement has been performed completely and continued to the next movement. The description mentioned previously is known as papakan stage. It is the initial stage of dance performed after the sungkem and illustrates the encounter between men and women.

This (papakan), before bringing Sodor property, is picturing an encounter between men and women. So, it starts with meetings. Next, the two human figures will run a married life and have sexual intercourse. (Shaman Keto, interviewed on April 2020)

The second stage of sodor dance is begun when pelandang distributes wuluh bamboo containing palawiji (corn seed, ketang, ucet) assisted by the assistance of Shaman to every dancer. Each of them holds a wuluh bamboo with right hand in a vertical position. Meanwhile, the left hand is placed on the chest with the palm of the hand open facing right. At this moment, the dancer prepares to wait for the musical instrument to begin the next movement. When the music starts, the dancers continue to dance.

The next movement is the movement of the left foot with the position of the left hand placed on the chest and head facing forward. In every movement, bamboo is stomped three times, causing a "kecrek" sound. After making a move with this tool, the dancers meet in the middle of the stage and continued hitting bamboo to each other. The movement of 'hitting bamboo' is performed by bending the body, the left leg is straight ahead and the right leg is placed behind to support the body. After the 'hitting bamboo' movement, the dancers is going to end the second stage of sodor dance. They turn their backs to each other to return to their original position. Finally, the last performance is breaking down the bamboos by hitting them to the floor until the palawiji inside each of the bamboo scattered. After that, bamboo wuluh is taken back again by the pelandang and the assistance of Shaman. A detailed description of the dance movement above using a property namely sodor is the second stage of the sodor dance called 'sodor fighting'.

The third stage of the dance after papakan and 'sodor fighting' is the salipan stage. In this stage, the dancers perform the dance exactly like the previous stage, but instead of meeting in the middle, they cross to each other and continue to dance until they are in the position of opposing lines. Then, they move back to its initial position. This movement is repeated 3 times before ended. Philosophically, the Sodoran dance is full of meaning. The Sodoran dance is a symbolic dance for the origin of human beings. In other words, The Sodoran dance symbolizes the meeting of men and women to sow the seeds of life. Therefore, the Sodoran dance can also be said as sangkan paran dance (the origin of humans in the world) (Sukmawan, 2018).

\subsection{The Meaning of Dance as Sex-education}

Movement in dance is the most basic foundation (Soedarsono, 1972:4). The movement is used as a medium of expression by making use of human body. The expression through movement is an imaginative statement outlined in the form of symbols (Minarto, 2013: 73). The symbol of certain movements implies meanings. The meaning of the first 3 times repeated movement of the Sodoran dance is the process of 'the first meeting' of men and women to get 
to know each other (the papakan / petukan movement). Creating awkward and timid nuances are shown in this initial movement of sodoran dance.

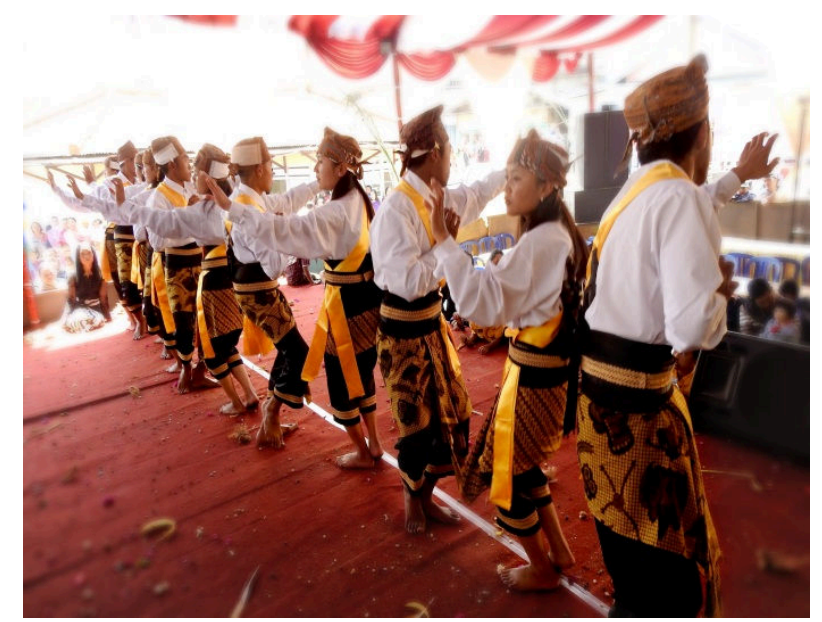

Figure 8 Papakan/Petukan movement

Next, the second 3 times repeated movement which shows the dancer closer to each other and moves to occupy the opposite line of dance symbolizes that they have been familiar and have had a relationship (married). Then, in the third 3 times repeated movements, all dancers meet in the middle of the stage. In this movement, dancers bring bamboo which is a symbol of the process of learning to settle down the clashing egos in familial life. Then, the fourth 3 times repeated movement is a 'reversal' movement by bringing bamboo. This is a symbol of a mature familial life. Then, in the next stage is the breaking down bamboo movement. This movement is a symbol of spreading seeds or making offspring (sodor fighting). After that, the dancers do 3 times meeting in the middle and 3 times crossing each other. This movement is a symbol of a complete familial life (salipan movement).

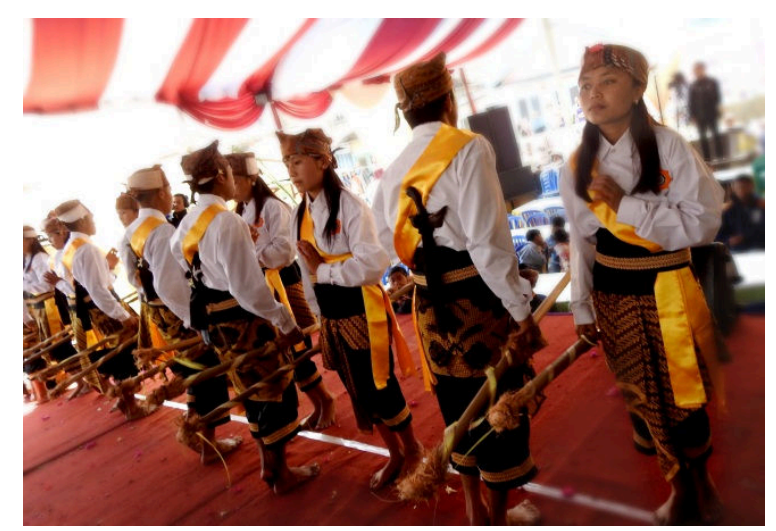

Figure 9. Salipan movement 
Another interpretation of the symbols of the three-repeated movement in Sodoran dance is the trilogy of life: birth-life-death (almost similar to rites of passage but more general). Even though the symbolic description of human life seems to be predominantly presented in a series of dances, the important message is related to the origin and purpose of life of human beings. Sangkan paraning dumadi is a philosophy of the life of Javanese used as a guiding reference to express insight of humans, God, and the natural environment. In works of art, this philosophy is paralogical, metaphysical, symbolic, and mysteriously enigmatic. In the Bedoyo dan Serimpi dance, for example, convey the meaning of human origins (Hartono, 2000).

The philosophy is the meeting of men and women. So, it starts with meetings. Next, the two of them will have been running a married life therefore there is a [symbolical] depiction of sexual intercourse. After that, it is the journey of familial life. In this part, the dancers are depicted salipan (crossing each other). This journey must be done and must be careful not to let any obstacle ruin the journey. At the end of the dance, Sodor must be broken down. It describes the process of procreation, a process of fertilization involving a sperm fusing with an ovum. After undergoing the journey, it will be ended by separation. The separation from a member of the family indicates paraning dumadi (towards the Almighty). There are birth, life, and death. The cycle of humans' journey of life displaying where they are from and where they are going back to. (Shaman Keto, interviewed on April 2020)

After all the whole stages of dance are finished, the shaman recites a mantra (spell) for holy water to assure agricultural prosperity. After that, the dancers are given the holy water. Every time sodoran dance is performed, it is always performed in synchronized and harmonious movements following the music. Body movements, music, and emotion, in the Javanese concept, are known as wiraga, wirama, and wirasa. Wiraga is related to gestures performed by dancers. Wirama refers to the dancer's movements and rhythm of dance, and Wirasa is related to the emotion involved by the dancers in performing the dance. Dance movements, musical arrangement, and emotion are unifying elements that embody a value of beauty (Sari, 2000:11).

Every night, before the dancers perform the dance, they will gather at Sanggar Pamujan and be given a lecture by the Shaman. Among other things is the philosophy of each movement performed in the Sodoran dance. That is, the Sodoran dance is a sangkan paran dance. It was straightforwardly discussed that the Sodoran dance implies sexuality education (eduseks) for the doers (dancers) particularly and for the younger generation generally. The results of Utomo et al's study (in Pakasi et al, 2013) said that although there are no specific subjects of sexuality education, this has been integrated into the Physical Education, Biology, Social Sciences, and Religious subjects. However, sexuality education that has been provided in schools seems to have less impact.

Sexuality education provided in schools has not sufficiently empowered teenagers to understand their sexuality and avoid sexual behavior that is risky to their reproductive health. Supposedly, sexuality education provides information for them related to self-protection and their sexuality. Therefore, informal education is needed as a means to provide an understanding of sexuality education more adequately. Art is a cultural instrument that can be used to convey educational messages informally. The Sodoran dance does not merely contain educational messages but this sacred dance fulfills four functions at once, namely the means of ceremony, entertainment, performance, and educational media (Jazuli, 1994). As a means of ceremony, Sodoran is a media of offering or worship to obtain salvation or happiness. As a medium of entertainment, Sodoran is intended to enliven or celebrate the feast of Karo ceremony. As a performance, Sodoran always provides an aesthetic and religious experience 
to the audience. Equally important, as an educational medium, Sodoran conveys sublime sexuality education.

It must be admitted that social norms still consider sex taboo to be discussed overtly. Only limited to those who are adults, sex and sexuality can be talked about. Sodoran dance is an entry point to convey important values particularly the values of sangkan paran which is delivered covertly as Tenggerese norms ask to in discussing sexuality. Sodoran dance as an educational medium is in line with the characteristics and interests of teenagers in Tengger due to its performative display. Moreover, the dance is supporting government policies related to the cultural promotion.

\section{Conclusion}

Karo and Sodoran dance have contained the virtues for humans and their universe manifested in various aspects of the ceremony. The main virtue delivered within this ceremony is related to where life comes from, how life is carried out, and where this life will end simply said as a life cycle. This kind of virtues is not obtained directly in school. Therefore, through Karo and Sodoran dance the learning process of knowing and understanding an important value mentioned above must be done creatively. A lesson that will benefit Tengger's younger generation for understanding taboo things. Thus, Sodoran dance is a cultural method in providing intromission education to them. In order for the message to be accepted fully and comprehensively, the medium for communicating the virtue must be coherent not only with the age of targeted audiences but also the norms held by them. How, then, the form of communication that is needed to communicate the virtue?

First, it is called communication through literary works formally and informally. Formally, 'literary-kind' of communication can be done by providing more local content in their school curriculum. This local content will assure local wisdom which is learned in school more relevant for students. Informally, 'literary-kind' communication can be designed in the community and carried out by the community itself. To implement it, the adults must know and understand well the virtue contained in Karo and Sodoran dance. Thus, the communication will be comprehensive and will be supportive in maintaining and sustaining the tradition itself.

The second is communication through ritual. 'Ritual-kind' communication plays a very important role. Ritual is a real educational apparatus because people or society involved in its process, become important parts of the ritual. In other words, this kind of communication can provide everyone involved with a sacred atmosphere. This is important because it will connect directly to the psychological realm of the doers of the ritual. If both kinds of communication are carried out optimally and continuously, then titiluri will be rightly implemented by integrating action and moral teachings understanding as a holistic package. If so, the presence of Sodoran is not understood merely as an old-fashioned and rigid tradition, but an adaptive and solutive tradition in responding to the latest challenges.

\section{References}

[1] Endraswara, Suwardi. 2018. Metodologi Penelitian Gastronomi Sastra. Yogyakarta:Textium. 
[2] Hartono. 2000. Seni Tari Dalam Persepsi Masyarakat Jawa. Harmonia: Jurnal Pengetahuan dan Pemikiran Seni, 1(2). Hlm. 52.

[3] Jazuli, M. 1994. Telaah Teoritis Seni Tari. Semarang: IKIP Semarang Press.

[4] Minarto, Soerjo Wido. 2013. Pemahaman Teknik Sebagai Dasar Pengembangan Tari Tradisional. Jurnal TEROB, 4(1). Hlm. 72-94.

[5] Minarto, Soerjo Wido. 2008. Struktur Simbolik Dramatari Wayang Topeng pada Dramatari Wayang Topeng Malang Di Dusun Kedungmonggo Desa Karangpandan Kecamatan Pakisaji Kabupaten Malang. Tesis tidak diterbitkan. Magister Pendidikan Seni di UNNES Semarang.

[6] Nurmansyah, M. A., Setiawan, F. N., Eka, S. V., \& Nufiarni, R. 2019. Tayub Dance within the Realm of Karo Ritual of Ngadas Village

[7] Tenggerese. In ICEL 2019: First International Conference on Advances in Education, Humanities, and Language, ICEL 2019, Malang, Indonesia, 23-24 March 2019 (p. 288). European Alliance for Innovation.

[8] Pakasi, Diana Teresa dan Reni Kartikawati. 2013. Antara Kebutuhan dan Tabu: Pendidikan Seksualitas dan Kesehatan Reproduksi bagi Remaja di SMA. 17(2): 7987. Makara Seri Kesehatan. (online). (http://www.academia.edu/ download/ 33338531/3030-5679-1-SM.pdf) Diakses pada tanggal 21 Mei 2020.

[9] Ratih, E. K., \& Juwariyah, A. 2020. Konstruksi Sosial Upacara Adat Karo Suku Tengger di Desa Tosari, Kecamatan Tosari, Kabupaten Pasuruan. Jurnal Analisa Sosiologi, 9(2).

[10] Sari, Mey Kartika. 2015. Biografi Tri Broto Wibisono, Konsep dan Pandangan Terhadap Seni Tari, (online), (https://jurnalmahasiswa.unesa.ac.id/ index.php/ apron/ article/view/12356), diakses 25 Mei 2020.

[11] Soedarsono. 1972. Djawa dan Bali, Dua Pusat Perkembangan Drama Tari Tradisional di Indonesia. Yogyakarta: Gajah Mada University Press.

[12] Sukmawan, Sony. 2017. Perempuan Tengger dalam Folklor. Makalah. Disajikan dalam International Conference on Language and Education di STKIP PGRI Pasuruan, 6-7 September.

[13] Sukmawan, Sony. 2018. Sesajen Tengger dalam Perspektif Arkeologis, Folkloristik dan Sastra Lisan. Makalah disajikan dalam Seminter ECKLL VI Universitas Dr. Soetomo Surabaya, Juli 2018. 